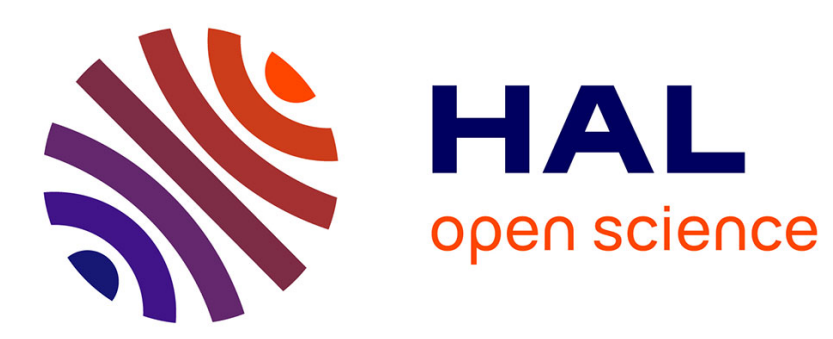

\title{
Powellite-Rich Glass-Ceramics: A Spectroscopic Study by EPR and Raman Spectroscopy
}

T Taurines, Delphine D. Neff, B Boizot

\section{To cite this version:}

T Taurines, Delphine D. Neff, B Boizot. Powellite-Rich Glass-Ceramics: A Spectroscopic Study by EPR and Raman Spectroscopy. Journal of the American Ceramic Society, 2013, pp.1-7. 10.1111/jace.12401 . cea-01120956

\section{HAL Id: cea-01120956 https://hal-cea.archives-ouvertes.fr/cea-01120956}

Submitted on 27 Feb 2015

HAL is a multi-disciplinary open access archive for the deposit and dissemination of scientific research documents, whether they are published or not. The documents may come from teaching and research institutions in France or abroad, or from public or private research centers.
L'archive ouverte pluridisciplinaire HAL, est destinée au dépôt et à la diffusion de documents scientifiques de niveau recherche, publiés ou non, émanant des établissements d'enseignement et de recherche français ou étrangers, des laboratoires publics ou privés. 


\title{
Powellite-rich glass-ceramics: a spectroscopic study by EPR and Raman spectroscopy
}

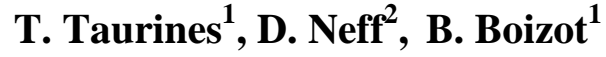

(1) Laboratoire des Solides Irradiés, UMR 7642 CEA-CNRS-Ecole Polytechnique, 91128 Palaiseau, France

(2) Service Interdisciplinaire sur les Systèmes Moléculaires et les Matériaux, UMR 3299 CEA-CNRS, 91190 Gif sur Yvette, France

\begin{abstract}
The aim of this study is to better understand the incorporation of rare earth elements in glassceramics of nuclear interest. We synthesized glass-ceramics from glasses in the system $\mathrm{SiO}_{2^{-}}$ $\mathrm{B}_{2} \mathrm{O}_{3}-\mathrm{Na}_{2} \mathrm{O}-\mathrm{CaO}-\mathrm{Al}_{2} \mathrm{O}_{3}-\mathrm{MoO}_{3}-\mathrm{Gd}_{2} \mathrm{O}_{3}$ by various heat treatments. Gadolinium is used both as a spectroscopic probe and as a minor actinide surrogate. Glass-ceramics contain only one crystalline phase in the bulk: powellite $\left(\mathrm{CaMoO}_{4}\right)$. This phase can incorporate $\mathrm{Gd}^{3+}$ and $\mathrm{Na}^{+}$ ions by substitutions on the Ca site. We demonstrated that the charge compensation by $\mathrm{Na}^{+}$ favors the rare earth elements incorporation. Moreover, the incorporated elements do not seem to be randomly distributed into the powellite structure.
\end{abstract}

\section{Introduction}

Molybdenum is known to be poorly soluble in borosilicate glasses and to easily induce phase separation during cooling processes $[1,2,3]$. Since Mo is an abundant fission product during reactions in nuclear fuel, its concentration can be problematic for high level waste conditioning [4]. Particularly, after the reprocessing of old fuel rods used in gas cooled reactors during the $20^{\text {th }}$ century or when the charge load of glasses is too high (usually above $18.5 \mathrm{wt} \%$ of fission products and minor actinides for the French R7T7 glass). 
Above its solubility limit $(\approx 1 \mathrm{~mol} \%)$, Mo can lead to the formation of crystalline phases like powellite $\left(\mathrm{CaMoO}_{4}\right)$ or $\mathrm{Na}_{2} \mathrm{MoO}_{4}$ distributed in the volume and even to the separation at the macroscopic scale of a complex phase mainly containing alkaline and alkaline-earth molybdates called the "yellow phase" $[5,6] . \mathrm{Na}_{2} \mathrm{MoO}_{4}$ and the "yellow phase" can drastically impact the immobilization properties of the glass since they are highly soluble in water and can carry radioactive elements like ${ }^{137} \mathrm{Cs}$. On the contrary, the powellite phase could be convenient for nuclear storage applications. Powellite has a tetragonal scheelite structure and crystallizes in the $\mathrm{I}_{1} / \mathrm{a}$ group ( $\mathrm{a}=5.225 \AA, \mathrm{c}=11.433 \AA$ ) [7]. This phase is of particular interest for nuclear waste immobilization since it is poorly soluble in aqueous solutions and allows to incorporate high quantities of $\mathrm{MoO}_{3}$ in glass-ceramics [8]. Moreover, studies under external irradiation showed that it is highly resistant to amorphisation. Under a Transmission Electron Microscope (TEM) beam, powellite amorphisation begins between $10^{12}$ and $10^{13}$ Gy [9] which is a dose much higher than the one received during underground storage $\left(<10^{10} \mathrm{~Gy}\right)$. Swift heavy ion irradiations made by Mendoza et al. [10] also showed a high resistance to amorphisation since no metamictisation has been detected by Raman spectroscopy and X-ray diffraction up to $10 \mathrm{dpa}$.

In $\mathrm{CaMoO}_{4}, \mathrm{Ca}^{2+}$ ions can be substituted by various elements. Indeed powellite is known to incorporate rare-earth elements and doped crystals have widely been studied for their laser performances and emission properties [11, 7]. Various insertion schemes are possible and have been reported in the literature. The most common substitution is $2 \mathrm{Ca}^{2+} \leftrightarrow$ $\left(\mathrm{RE}^{3+}, \mathrm{R}^{+}\right)$with $\mathrm{RE}^{3+}$ a trivalent rare-earth and $\mathrm{R}^{+}$a monovalent ion $[12,13,14]$. This coupled substitution ensures the lattice electro neutrality and favors the dopant incorporation [15]. Other substitutions like $3 \mathrm{Ca}^{2+}$ by $2 \mathrm{RE}^{3+}$ plus a vacancy or $\left(\mathrm{Ca}^{2+}, \mathrm{Mo}^{6+}\right)$ by $\left(\mathrm{RE}^{3+}, \mathrm{Z}^{5+}\right)$ are also possible $[12,15]$. Doped scheelite structures can exhibit a random distribution of the inserted elements $[12,16,17]$ or an ordered insertion which can lead to the formation of 
superstructures $[12,14,16]$. In powellite-rich glass-ceramics, the crystalline phase could act as a good host for actinides and therefore improve the immobilization properties.

For that purpose, we have developed model glass-ceramics containing monodiperse powellite crystals from glasses in the system $\mathrm{SiO}_{2}-\mathrm{B}_{2} \mathrm{O}_{3}-\mathrm{Na}_{2} \mathrm{O}-\mathrm{CaO}-\mathrm{Al}_{2} \mathrm{O}_{3}-\mathrm{MoO}_{3}-\mathrm{Gd}_{2} \mathrm{O}_{3}$. The micro-structure was mainly controlled by various heat treatments described in the experimental methods. The obtained glass-ceramics contain powellite crystals well dispersed into the residual glass, with various size distributions and concentrations. Crystal sizes range from a few tens of nanometers to a few micrometers depending of $\mathrm{MoO}_{3}$ content and heat treatments[18]. For nuclear waste immobilization, the partitioning ratio of radioelements between the glassy and the crystalline phases is a matter of concern. That is why this study addresses the speciation of $\mathrm{Gd}^{3+}$ ions in the glassy and the powellite phases by electron paramagnetic resonance (EPR) and Raman spectroscopy. At low $\mathrm{Gd}_{2} \mathrm{O}_{3}$ doping content $(0.15$ $\mathrm{mol} \%), \mathrm{Gd}^{3+}(\mathrm{S}=7 / 2)$ is used as an EPR spectroscopic probe whereas at higher content, $\mathrm{Gd}^{3+}$ ions could be considered as a trivalent minor actinide surrogate mainly of $\mathrm{Np}^{3+}, \mathrm{Am}^{3+}$ and $\mathrm{Cu}^{3+}$. We particularly studied the effects of composition and heat treatments on the incorporation of $\mathrm{Gd}^{3+}$ ions into the powellite structure.

\section{Experimental methods}

\section{Glass-ceramics preparation}

For this study, we prepared glasses in the system: $\mathrm{SiO}_{2}-\mathrm{B}_{2} \mathrm{O}_{3}-\mathrm{Na} a_{2} \mathrm{O}-\mathrm{CaO}-\mathrm{Al}_{2} \mathrm{O}_{3}$. Increasing amounts of $\mathrm{MoO}_{3}$ are added, from 0.5 to $4.5 \mathrm{~mol} \%$ in order to have a wide range in powellite concentration in the glass-ceramics. $\mathrm{Gd}_{2} \mathrm{O}_{3}$ is added at $0.15 \mathrm{~mol} \%$ and $1 \mathrm{~mol} \%$ contents.

(i) Series Mxg : $(0.9985-2 x / 100)\left(61.16 \mathrm{SiO}_{2}-16.28 \mathrm{~B}_{2} \mathrm{O}_{3}-12.85 \mathrm{Na}_{2} \mathrm{O}-3.88 \mathrm{Al}_{2} \mathrm{O}_{3}-\right.$ 5.82CaO) - $\mathrm{x} \mathrm{CaO}-\mathrm{x} \mathrm{MoO}_{3}-\mathbf{0 . 1 5} \mathbf{G d}_{2} \mathbf{O}_{3}$ (in mol\%) with $\mathrm{x}=0,0.5,1.5,2.5,3.5$ and 4.5. 
(ii) Series Mxg1: $(0.99-2 \mathrm{x} / 100)\left(61.16 \mathrm{SiO}_{2}-16.28 \mathrm{~B}_{2} \mathrm{O}_{3}-12.85 \mathrm{Na}_{2} \mathrm{O}-3.88 \mathrm{Al}_{2} \mathrm{O}_{3}-\right.$ 5.82CaO) - $\mathrm{x} \mathrm{CaO}-\mathrm{x} \mathrm{MoO}_{3}-\mathbf{1} \mathbf{G d}_{2} \mathbf{O}_{3}($ in $\mathrm{mol} \%$ ) with $\mathrm{x}=0,0.5,1.5,2.5,3.5$ and 4.5.

In the two series, $\mathrm{CaO}$ oxide was added in increasing amounts to the baseline glass composition to compensate the loss during powellite crystallization. Therefore the residual glass compositions of each series can be kept constant if all the molybdenum is incorporated into the powellite crystals.

Parent glasses were prepared by mixing desired amounts of reagent grade $\mathrm{SiO}_{2}, \mathrm{H}_{3} \mathrm{BO}_{3}$, $\mathrm{Na}_{2} \mathrm{CO}_{3}, \mathrm{Al}_{2} \mathrm{O}_{3}, \mathrm{CaCO}_{3}, \mathrm{MoO}_{3}$ and $\mathrm{Gd}_{2} \mathrm{O}_{3}$. Each batch $(\sim 30 \mathrm{~g})$ was melted at $1500^{\circ} \mathrm{C}$ for $3+$ 2 hours before being quenched on a copper plate. Then all samples were annealed at $500^{\circ} \mathrm{C}$ to relieve internal stresses. The melting process was described in more details elsewhere [18]. Ceramics were elaborated with three chemical compositions: pure powellite $\mathrm{CaMoO}_{4}$, powellite doped with $0.015 \mathrm{~mol} \%$ of $\mathrm{Gd}_{2} \mathrm{O}_{3}$ (later mentioned as $\mathrm{CaMoO}_{4}$-Gd) and powellite doped with 0.015 mol\% of $\mathrm{Gd}_{2} \mathrm{O}_{3}$ with a charge compensation (later mentioned as $\mathrm{CaMoO}_{4}$ Gd-Na). The charge compensation was ensured by replacing $\mathrm{CaO}$ by $1 / 2 \mathrm{Na}_{2} \mathrm{O}$ to compensate the charge excess due to the insertion of $\mathrm{Gd}^{3+}$ ions into the powellite structure. Appropriate amounts of reagents were grounded and calcined at $800^{\circ} \mathrm{C}$ for 6 hours. Then pellets were obtained with a mechanical press $(\mathrm{P}=350 \mathrm{MPa})$ and sintered at $1150^{\circ} \mathrm{C}$ for 15 hours under air, with $5^{\circ} \mathrm{C} / \mathrm{min}$ rates for heating and cooling. 


\section{Heat treatments}

Two different crystallization methods were investigated to control the size and the concentration of powellite crystals in the glass-ceramics. Since powellite crystallization is strongly dependent on cooling rates $[19,20]$, we paid attention to perform all the cooling stages the same way. The nucleation temperature was chosen at $820^{\circ} \mathrm{C}$ according to literature and differential thermal analysis (DTA) $[10,21,22]$. The growth temperature was chosen at $1050^{\circ} \mathrm{C}$

(i) The first method consists of a long nucleation stage at $820^{\circ} \mathrm{C}$ for 110 hours. Samples were placed into a pre-heated furnace and quenched in air. This heat treatment is labeled $\mathrm{N}$ (for nucleation).

(ii) The second method consists of three stages. Samples were placed into a pre-heated furnace for a short nucleation phase at $820^{\circ} \mathrm{C}$ for 2 hours. The temperature was then raised to $1050^{\circ} \mathrm{C}$ with an $8^{\circ} \mathrm{C} / \mathrm{min}$ rate for a 20 hours growth stage. After being air quenched, the samples were placed again into the furnace at $820^{\circ} \mathrm{C}$ for 112 hours. This heat treatment is labeled NG (for nucleation-growth).

The last nucleation stage of the second method was necessary to reach the same powellite concentration obtained during the first heat treatment. Indeed, since the dissolution temperature is close to the nucleation temperature [19], some powellite crystals can dissolve during the growth stage. All samples were annealed at $500^{\circ} \mathrm{C}$ for 2 hours to release internal stresses.

\section{Samples characterization}

EPR measurements were done at room temperature on a $\mathrm{X}$ band $(v=9.86 \mathrm{GHz})$ EMX Bruker (Wissembourg, France) EPR spectrometer using a $100 \mathrm{kHz}$ field modulation and 3 Gauss of amplitude modulation. Microwave power of $1 \mathrm{~mW}$ was used to study $\mathrm{Gd}^{3+}$ and $\mathrm{Mo}^{5+}$ 
ion environments. For EPR line analysis, the line width was calculated between maximum and minimum.

Micro-Raman spectroscopy was performed using a Renishaw INVIA (Wotton-underEdge, U. K.) spectrometer equipped with a doubled frequency Nd:YAG laser at $532 \mathrm{~nm}$. The laser was focused on the sample using a Leica microscope with a 50X objective, the spectral resolution achievable by the $\mathrm{CCD}$ detector is around $2 \mathrm{~cm}^{-1}$. Spectra were recorded between 200 and $1600 \mathrm{~cm}^{-1}$ with a $24001 / \mathrm{mm}$ grating. A linear base line was subtracted from each spectrum which was then normalized to the main peak of powellite. Full Width at Half Maximum (FWHM) of the main powellite peak was calculated after a peak fitting by a pseudo Voigt function.

Chemical analysis of powellite crystals were done on a CAMECA SX 100 electron microprobe analyzer (CAMECA, Gennevilliers, France) equipped with four X-ray spectrometers with an acceleration voltage of $15 \mathrm{kV}$ and a current of $4 \mathrm{nA}$. Analysis of powellite crystals was conducted on samples obtained by the NG heat treatment since the minimum crystal size needs to be a few micrometers.

\section{Results}

\section{$\mathbf{G d}^{3+}$ incorporation in polycrystalline powellite}

To better understand $\mathrm{Gd}^{3+}$ ions incorporation into the powellite structure, polycrystalline ceramics were characterized by EPR and Raman spectroscopy.

EPR spectra of the ceramics $\mathrm{CaMoO}_{4}-\mathrm{Gd}$ and $\mathrm{CaMoO}_{4}-\mathrm{Gd}-\mathrm{Na}$ are depicted on figure 1. The only paramagnetic species in these ceramics samples is the $\mathrm{Gd}^{3+}$ ion $(\mathrm{S}=7 / 2)$. We assumed therefore that all EPR lines could be attributed to the complex fine structure of $\mathrm{Gd}^{3+}$ ions $(\mathrm{S}=7 / 2)$ in different environments. Moreover the EPR spectra of Gd-containing powellites is close to spectra of molybdate and tungstate phases containing isolated $\mathrm{Gd}^{3+}$ ions 
at low content [23]. The study of saturation properties of several EPR lines (not shown here) revealed that $\mathrm{Gd}^{3+}$ ions enter the powellite structure with at least three different environments. The comparison of the EPR spectra leads to two important points. First, the area under the EPR spectra is much more important for the ceramic with the charge compensation than for the other ceramic. Since the EPR intensity is proportional to the $\mathrm{Gd}^{3+}$ ions concentration, the insertion of these ions into the powellite structure is highly favored by the charge compensation. Second, the EPR lines of the $\mathrm{CaMoO}_{4}-\mathrm{Gd}-\mathrm{Na}$ ceramic are wider than the ones of the $\mathrm{CaMoO}_{4}-\mathrm{Gd}$ ceramic (see zoom on figure 1). This widening could be due to dipoledipole interaction close to $\mathrm{Gd}^{3+}$ ions. Therefore, the $\mathrm{Gd}^{3+}$ ions environment is different in the two ceramics. These differences reveal that the insertion of $\mathrm{Gd}^{3+}$ ions into the powellite structure was strongly modified by the charge compensation allowed by the $\mathrm{Na}^{+}$ions. However, no new EPR lines are observed on the $\mathrm{CaMoO}_{4}-\mathrm{Gd}-\mathrm{Na}$ spectrum, which means that the $\mathrm{Gd}^{3+}$ ions environment is not strongly modified by the presence of $\mathrm{Na}^{+}$ions in the structure.

Raman spectra of the three ceramics are given on figure 2 . The structure of the spectra is the same as the one commonly reported for scheelite structures [24, 25]. Seven internal modes, corresponding to the vibration of the $\mathrm{MoO}_{4}{ }^{2-}$ tetrahedron, are observed in $\mathrm{CaMoO}_{4}$. The breathing vibration $v_{1}\left(\mathrm{~A}_{\mathrm{g}}\right)$ of the $\mathrm{MoO}_{4}{ }^{2-}$ tetrahedron appears at $878 \mathrm{~cm}^{-1}$. The modes $v_{3}\left(B_{g}\right), v_{3}\left(E_{g}\right), v_{4}\left(E_{g}\right)$ and $v_{4}\left(B_{g}\right)$ are respectively observed at 848, 795, 405 and $393 \mathrm{~cm}^{-1}$. The doubly degenerated modes $v_{2}\left(A_{g}+B_{g}\right)$ appear around $330 \mathrm{~cm}^{-1}$. All spectra were normalized to the intensity of the main peak at $878 \mathrm{~cm}^{-1}$ (called peak A) since it is the less influenced by the beam orientation [26]. All peaks are attributed to $\mathrm{CaMoO}_{4}$ except one, which is only observed if $\mathrm{Gd}^{3+}$ and $\mathrm{Na}^{+}$ions are in the powellite structure. Indeed, a peak, labeled $\mathrm{B}$, grows around $907 \mathrm{~cm}^{-1}$ when $\mathrm{Gd}_{2} \mathrm{O}_{3}$ and $\mathrm{Na}_{2} \mathrm{O}$ oxides are added to pure powellite. Moreover, XRD analysis showed that no secondary crystalline phases are detected in the $\mathrm{CaMoO}_{4}-\mathrm{Gd}-\mathrm{Na}$ 
ceramic. The width of the peak $\left(\sim 15 \mathrm{~cm}^{-1}\right)$ seems to indicate that it could be linked to a vibration mode of an ion in an ordered environment. A similar peak was reported in literature for polycrystalline powellites enriched with trivalent rare earth elements $\left(\mathrm{Eu}^{3+}, \mathrm{Nd}^{3+}, \mathrm{La}^{3+}\right.$, $\left.\mathrm{Pr}^{3+}\right)$ and monovalent charge compensators $\left(\mathrm{Na}^{+}, \mathrm{Sr}^{+}\right)$[10]. Possible attributions for this unidentified Raman peak will be discussed later.

\section{$\mathrm{Gd}^{3+}$ incorporation in $\mathrm{CaMoO}_{4}$ rich glass-ceramics}

The microstructure of the samples from the series Mxg and Mxg1 were studied elsewhere [18]. Depending on the molybdenum and gadolinium contents, samples can either be amorphous or partially crystallized. The results presented here address the incorporation of gadolinium ions in the glassy phase and into the powellite structure.

The evolution of the M25g sample EPR spectrum with heat treatments is plotted on figure 3. The spectra are complex and result from various signals. First, several narrow EPR lines are observed (indexed by arrows on figure 3 ). They are attributed to $\mathrm{Gd}^{3+}$ ions incorporated into powellite structure by comparison with the spectra of ceramics reported on figure 1. Second, we find the well known "U spectrum" with the wide lines at $g=2,2.8$ and 6 attributed to $\mathrm{Gd}^{3+}$ ions diluted in the glass in network modifier position $\left(\mathrm{Gd}_{[\mathrm{n} . \mathrm{m}]}\right)$ and the line at $\mathrm{g}=4.6$ attributed to $\mathrm{Gd}^{3+}$ ions acting as network formers $\left(\mathrm{Gd}_{[\mathrm{n} . \mathrm{f}]}\right)$ [27]. A very wide line is also observed on all EPR spectra, this signal is linked to the formation of magnetic oxide clusters of $\mathrm{Gd}^{3+}$ ions, linked through the oxygen bridges [28]. The presence of magnetic clusters was also confirmed by low temperature EPR measurements at $150 \mathrm{~K}$. Finally, a second paramagnetic species was identified, since an extra line at $\mathrm{g}=1.91$ is observed. This line appears only in glasses and glass-ceramics containing $\mathrm{MoO}_{3}$ and is attributed to $\mathrm{Mo}^{5+}$ ions diluted in the glass structure $[4,29,30]$. With increasing the Mo content in parent glasses, the intensity of the line attributed to $\mathrm{Mo}^{5+}$ ions increases as already reported in literature [31]. The same trend is observed with the lines attributed to $\mathrm{Gd}^{3+}$ ions incorporated 
into the powellite structure. This increase is linked to the increase of powellite quantity in the glass-ceramics [18]. After the two heat treatments, some evolutions are visible in the EPR spectrum. First, the signal of $\mathrm{Mo}^{5+}$ ions decreases during heat treatments, particularly with the treatment $\mathrm{NG}$ during the growth phase at $1050^{\circ} \mathrm{C}$. Second, the intensity of lines attributed to $\mathrm{Gd}^{3+}$ ions incorporated into the $\mathrm{CaMoO}_{4}$ structure increases with heat treatments. This evolution seems similar for the two heat treatments and could be due to an increase of powellite quantity and/or to an increase of the incorporation rate during the heat treatments.

EPR spectra of the M25g1 sample $\left(1 \mathrm{~mol} \% \mathrm{Gd}_{2} \mathrm{O}_{3}\right)$ before and after heat treatments are given on figure 4. These spectra are quite different from the ones of the M25g sample containing only $0.15 \mathrm{~mol} \%$ in $\mathrm{Gd}_{2} \mathrm{O}_{3}$. First, the intensity of the broad signal due to magnetic oxide clusters of $\mathrm{Gd}^{3+}$ ions is far more intense. This means that an important part of the added $\mathrm{Gd}_{2} \mathrm{O}_{3}$ forms clusters in the glass rather than being part of the glassy network. Indeed the contribution of the "U spectrum" of $\mathrm{Gd}^{3+}$ ions involved in the glassy network is similar for the two gadolinium oxide contents. Nevertheless, the line at $\mathrm{g}=4.6$, attributed to $\mathrm{Gd}^{3+}$ ions acting as network formers, is no longer visible. The lines attributed to $\mathrm{Gd}^{3+}$ incorporated into powellite are also difficult to distinguish but are present. It seems that these lines are very broad, which could be due to dipole-dipole interactions because of a higher incorporation rate. The comparison of the two incorporation rates is, however, not possible because of the complexity of the EPR spectra. This point will be discussed later. Moreover, the line at $\mathrm{g}=$ 1.91 attributed to $\mathrm{Mo}^{5+}$ ions diluted in the glass is barely visible.

Because of the complexity of the spectra, the relative proportion of $\mathrm{Gd}^{3+}$ ions incorporated into the $\mathrm{CaMoO}_{4}$ structure is difficult to calculate. Nevertheless, the mean widths of Gaussian lines attributed to $\mathrm{Gd}^{3+}$ ions into powellite can be calculated to compare ions environments. The mean widths were calculated on six Gaussian lines for the series Mxg, Mxg-N and Mxg-NG and are plotted on figure 5. The width for samples from the series Mxg 
and Mxg-N are similar whatever the Mo content is. Therefore the $\mathrm{Gd}^{3+}$ ions environment is similar in these glass-ceramics. However, the trend is different for the series Mxg-NG. Indeed, the mean width is higher than for samples from the other series and it decreases with the Mo content increase. The ions environments are then different and could be linked to the concentration of inserted ions into the powellite structure.

Raman spectra of samples from the series Mxg-N and Mxg1-N are plotted on figure 6, (a). First, the powellite main peak, A, is broader for the Mxg1-N samples than for the Mxg-N samples. This means that the powellite phase is more disordered when the samples contain more gadolinium. The same observation is made for samples after the NG heat treatment. This trend is better illustrated on figure 7 which depicts peak A FWHM evolution with $\mathrm{MoO}_{3}$ content $(\mathrm{mol} \%)$ in glass-ceramics. First, we clearly see that for samples with high content of gadolinium, the peaks are wider than for samples with low content. Second, after NG heat treatment the powellite peak is broader than after $\mathrm{N}$ heat treatment. This means that powellite crystals are, on average, more disordered after the NG heat treatment than after the $\mathrm{N}$ one. This disorder could be due to a higher incorporation rate of $\mathrm{Gd}^{3+}$ ions after the $\mathrm{NG}$ heat treatment. Back to figure 6 , we observe the peak $\mathrm{B}$, around $907 \mathrm{~cm}^{-1}$, on all samples. The relative intensity of peak B is higher for Mxg1 samples than for Mxg samples, for all thermal histories. This difference could be linked to higher Gd incorporation rates into the powellite structure for samples containing $1 \mathrm{~mol} \%$ in $\mathrm{Gd}_{2} \mathrm{O}_{3}$. To check this point, measurements with an electron probe micro-analyzer (EPMA) were performed on powellite crystals in samples from the Mxg-NG and Mxg1-NG series. After the NG heat treatment, few crystals are large enough to be probed by EPMA. These analyses show that for samples containing 1 mol\% in $\mathrm{Gd}_{2} \mathrm{O}_{3}$, the average composition of powellite crystals is $\mathrm{Ca}_{0.9} \mathrm{Gd}_{0 \cdot 05} \mathrm{Na}_{0.05} \mathrm{MoO}_{4}$ whereas it is $\mathrm{Ca}_{0.95} \mathrm{Gd}_{0 \cdot 015} \mathrm{Na}_{0 \cdot 015} \mathrm{MoO}_{4}$ for samples containing only $0.15 \mathrm{~mol} \%$ in $\mathrm{Gd}_{2} \mathrm{O}_{3}$. This means that 
Gd incorporation rates are higher in samples containing more $\mathrm{Gd}_{2} \mathrm{O}_{3}$, which is consistent with EPR and Raman spectra observations. Indeed, figure 8 depicts the evolution of peak A FWHM versus the total substitution rate on the Ca site measured by EPMA. The higher the substitution rate on $\mathrm{Ca}$ site is, the larger the peak $\mathrm{A}$ is. Moreover, these chemical analyses suggest that the incorporation mode of trivalent lanthanides into powellite structure is accompanied by the insertion of a monovalent ion $\mathrm{Na}^{+}$. Therefore, the main incorporation scheme is the replacement of two calcium ions by a gadolinium ion and a sodium ion.

\section{Discussion}

In this work, we studied powellite-rich glass-ceramics by EPR and Raman spectroscopy. We showed that gadolinium ions enter the powellite structure and that incorporation rates depend on synthesis processes, gadolinium content in parent glasses and availability of a charge compensator $\left(\mathrm{Na}^{+}\right)$. Chemical analyses, like with EPMA, are difficult to use for most of the samples developed during this work. Indeed, the small sizes (few hundred nanometers) and the distribution of crystals in the residual glasses make the analysis often impossible [19]. Therefore, it is very interesting to be able to link spectroscopic parameters, like Raman FWHM or EPR line width, to the incorporation rate into the powellite structure. Raman FWHM is usually linked to the disorder of the crystalline structure. In our case, the disorder is mainly due to the substitution of two calcium ions by a couple $\left(\mathrm{Gd}^{3+}\right.$, $\mathrm{Na}^{+}$). For some samples, we demonstrated that Raman FWHM increases with the insertion ratio (cf. fig. 8). Let us assume that the FWHM increase is only due to the increase of the insertion rate. Then powellite crystals obtained by the NG heat treatment have a higher insertion rate than the ones obtained by the $\mathrm{N}$ heat treatment. Besides, this higher insertion rate allows us to explain the evolution of EPR lines widths with heat treatment depicted on figure 5. The widening of EPR lines in samples obtained by the NG heat treatment can 
therefore be attributed to dipole-dipole interaction between close $\mathrm{Gd}^{3+}$ ions in the powellite structure. Even if the analysis of spectroscopic parameters does not give an absolute value of the Gd incorporation rate, it allows us to compare the insertion between the different series and after the heat treatments without the need of uneasy chemical analyses.

During this study, we observed a new peak (peak B) on powellite Raman spectra when $\mathrm{Gd}^{3+}$ and $\mathrm{Na}^{+}$ions are incorporated into the structure. This peak is also observed on glassceramics containing powellite and $\mathrm{Gd}_{2} \mathrm{O}_{3}$. Its relative intensity compared to the main peak of powellite increases with the incorporation rate and its FWHM is quite small (around $15 \mathrm{~cm}^{-1}$ ). According to literature $\mathrm{CaMoO}_{4}$ main peak is usually found between 877 and $879 \mathrm{~cm}^{-1}[10$, 32, 33, 31] and $\mathrm{Na}_{2} \mathrm{MoO}_{4}$ main peak is found between 891 and $897 \mathrm{~cm}^{-1}[34,35]$. This peak cannot be attributed to simple molybdates like $\mathrm{CaMoO}_{4}$ or $\mathrm{Na}_{2} \mathrm{MoO}_{4}$ since its position is 907 $\mathrm{cm}^{-1}$. Therefore, we can assume that the peak B can be attributed to the presence of $\mathrm{Gd}^{3+}$ and $\mathrm{Na}^{+}$ions incorporated into the powellite. Several assumptions can then be made to attribute peak B. First, we can assume that this peak is due to a secondary phase of general composition $\mathrm{Ca}_{1-2 \mathrm{x}} \mathrm{Gd}_{\mathrm{x}} \mathrm{Na}_{\mathrm{x}} \mathrm{MoO}_{4}$. The main peaks of phases $\mathrm{CaMoO}_{4}$ and $\mathrm{GdNa}\left(\mathrm{MoO}_{4}\right)_{2}$ are respectively at 878 and $882 \mathrm{~cm}^{-1}$ [24]. Therefore, the main peak of $\mathrm{Ca}_{1-2 \mathrm{x}} \mathrm{Gd}_{\mathrm{x}} \mathrm{Na}_{\mathrm{x}} \mathrm{MoO}_{4}$ should be observed between 878 and $882 \mathrm{~cm}^{-1}$. Since peak B is around $907 \mathrm{~cm}^{-1}$, it cannot be attributed to a secondary phase of composition $\mathrm{Ca}_{1-2 \mathrm{x}} \mathrm{Gd}_{\mathrm{x}} \mathrm{Na}_{\mathrm{x}} \mathrm{MoO}_{4}$ unless its environment is strongly distorted. Indeed, the $\mathrm{Mo}-\mathrm{O}$ stretching frequency depends strongly on $\mathrm{MoO}_{4}{ }^{2-}$ tetrahedral environment [4]. For instance, the powellite main peak position can increase from $878 \mathrm{~cm}^{-1}$ to $900 \mathrm{~cm}^{-1}$ if the applied pressure increases from 1 to $8 \mathrm{GPa}[36,32]$. A similar trend was observed for the $\mathrm{Na}_{2} \mathrm{MoO}_{4}$ phase [34]. Second, we can assume that peak $\mathrm{B}$ is a splitting of the main peak of powellite. Peak A splitting has been reported in literature by Kolesov et al. for scheelite-like double molybdates $\mathrm{R}_{0.5} \mathrm{R}_{0.5}{ }^{\mathrm{MoO}} \mathrm{O}_{4}$ where $\mathrm{R}$ and $\mathrm{R}$ ' are respectively alkaline and rare earth metals [24]. The splitting of peak A depends on the radius 
ratio of $\mathrm{R}$ and $\mathrm{R}^{\prime}$ ions and it is attributed to an ordered distribution of these ions in the structure. Other authors, put in evidence ordered distributions in schellite like molybdates by other techniques like XRD, TEM or Monte Carlo simulation [37, 14]. Therefore, peak B could be due to an ordered distribution of $\mathrm{Gd}^{3+}$ and $\mathrm{Na}^{+}$ions on the octahedral $\mathrm{Ca}$ sites in the powellite structure. This assumption allows explaining the fact that no new EPR lines appear when $\mathrm{Na}^{+}$ions enter the powellite structure. Indeed, if $\mathrm{Na}^{+}$ions are not close enough to $\mathrm{Gd}^{3+}$ ions, their structural environment is not strongly modified and no EPR lines appear. In this case, the charge compensation by $\mathrm{Na}^{+}$is ensured at a medium or long distance. To conclude

on the attribution of peak $\mathrm{B}$, we can reasonably assume that it is due to the insertion of $\mathrm{Gd}^{3+}$ and $\mathrm{Na}^{+}$ions into the powellite structure with an ordered distribution. Nevertheless, further studies by high resolution TEM and advanced diffraction methods are needed to better characterize the insertion into the powellite structure.

\section{Conclusion}

In this work use of EPR and Raman spectroscopy revealed that gadolinium ions are incorporated into the powellite structure in all the glass-ceramics. The incorporation rate strongly depends on the charge compensation by $\mathrm{Na}^{+}$ions in pure ceramics. It also depends on the heat treatment and on the initial rare earth concentration in the parent glass for glassceramics. Raman spectroscopy suggests an ordered insertion of $\mathrm{Na}^{+}$and $\mathrm{Gd}^{3+}$ ions into the powellite structure. Nevertheless, further studies on highly doped powellite ceramics with high resolution TEM or advanced XRD Rietveld refinements are needed to better understand the distribution of incorporated elements into powellite. 


\section{Acknowledgements}

The authors acknowledge Mickaël Bouhier for the help during Raman analyses.

\section{References}

[1] C. Cousi, F. Bart, and J. Phalipou. "Phase separation and crystallization induced by adding molybdenum and phosphorus to a soda-lime-silicate glass", Glass Technol., 45, 6567, (2004).

[2] S. Schuller, O. Pinet, A. Grandjean, and T. Blisson. "Phase separation and crystallization of borosilicate glass enriched in $\mathrm{MoO}_{3}, \mathrm{P}_{2} \mathrm{O}_{5}, \mathrm{ZrO}_{2}, \mathrm{CaO}$, J. Non-Cryst. Solids, 354, 296$300,(2008)$.

[3] S. Schuller, O. Pinet, and B. Penelon. "Liquid-liquid phase separation process in borosilicate liquids enriched in molybdenum an phosphorus oxides", J. Am. Ceram. Soc., 94, 447-454, (2011).

[4] D. Caurant, O. Majérus, E. Fadel, A. Quintas, C. Gervais, T. Charpentier, and D. Neuville. "Structural investigations of borosilicate glasses containing $\mathrm{MoO}_{3}$ by $\mathrm{MAS}$ NMR and Raman spectroscopies”, J. Nucl. Mater., 396, 94-101, (2010).

[5] R.J. Short, R.J. Hand, and N.C. Hyatt. "Molybdenum in nuclear waste glasses incorporation, and redox state", Mater. Res. Soc. Symp. Proc., 757, 141-146, (2003).

[6] Y. Kawamoto, K. Clemens, and M. Tomozawa. "Effects of $\mathrm{MoO}_{3}$ on phase separation of $\mathrm{Na}_{2} \mathrm{O}-\mathrm{B}_{2} \mathrm{O}_{3}-\mathrm{SiO}_{2}$ glasses", J. Am. Ceram. Soc., 64, 292-96, (1981).

[7] E. Cavalli, E. Bovero, and A. Belleti. "Optical spectroscopy of $\mathrm{CaMoO}_{4}: \mathrm{Dy}^{3+}$ single crystals", J. Phys. Condens. Matter., 14, 5221-5228, (2002).

[8] P. Pascal. Complément au nouveau traité de chimie minérale, (1979). 
[9] J. V. Crum, B.J. Riley, L.R. Turo, M. Tang, and A. Kossoy. Summary report: Glassceramic waste forms for combined fission products. Technical report, U.S. Department of Energy Waste Form Campaign, (2011).

[10] C. Mendoza. Caractérisation et comportement sous irradiation de phases powellites dopées terres rares. Application au comportement à long terme des matrices de confinement des déchets nucléaires. PhD thesis, Université Claude Bernard, France, 2010.

[11] V. M. Longo and A. T. de Figueiredo. "Different origins of green-light photoluminescence emission in structurally ordered and disordered powders of calcium molybdate", J. Phys. Chem. A, 112, 8920-8928, (2008).

[12] V. Morozov, A. Mironov, B. Lazoryak, E. Khaikina, O. Basovich, M. Rossell, and G. Van Tendeloo. “ ${ }^{A} \mathrm{Ag}_{1 / 8} \mathrm{Pr}_{5 / 8} \mathrm{MoO}_{4}$ : An incommensurately modulated scheelite-type structure”, J. Solid State Chem., 179, 1183 - 1191, (2006).

[13] D. Bosbach, T. Rabung, F. Brandt, and T. Fanghänel. "Trivalent actinide coprecipitation with powellite $\left(\mathrm{CaMoO}_{4}\right)$ : Secondary solid solution formation during HLW borosilicate-glass dissolution”, Radiochimica Acta, 92, 639-643, (2004).

[14] V. L. Vinograd, D. Bosbach, B. Winkler, and J. D. Gale. "Subsolidus phase relations in $\mathrm{Ca}_{2} \mathrm{Mo}_{2} \mathrm{O}_{8}-\mathrm{NaEuMo}_{2} \mathrm{O}_{8}$-powellite solid solution predicted from static lattice energy calculations and Monte Carlo simulations", Phys. Chem. Chem. Phys., 10,3509-3518, (2008). [15] L.H.C. Andrade, M. Siu Li, Y. Guyot, A. Brenier, and G. Boulon. "Optical multi-sites of $\mathrm{Nd}^{3+}$-doped $\mathrm{CaMoO}_{4}$ induced by $\mathrm{Nb}^{5+}$ charge compensator", J. Phys. Condens. Matter., 18, 7883-7892, (2006).

[16] M. Schieber and L. Holmes. "Crystal growth and magnetic susceptibilities of some rareearth sodium molybdenum scheelites”, J. Appl. Phys., 35, 1004-1005, (1964).

[17] D. Zhao, F. Li, W. Cheng, and H. Zhang. "Scheelite-type $\operatorname{NaEr}\left(\mathrm{MoO}_{4}\right)_{2}$ ", Acta. Cryst., E66:i36, (2010). 
[18] T. Taurines and B. Boizot. "Microstructure of powellite-rich glass-ceramics : a model system for high level waste immobilization”, J. Am. Ceram. Soc., 95,1105-1111, (2012).

[19] M. Magnin. Etude des processus de démixtion et de cristallisation au sein de liquides fondus borosilicatés riches en oxyde de molybdène. $\mathrm{PhD}$ thesis, Université Pierre et Marie Curie, France, (2009).

[20] T. Taurines and B. Boizot. "Synthesis of powellite-rich glasses for high level waste immobilization", J. Non-Cryst. Solids, 357, 2723-2725, (2011).

[21] X. Orlhac. Étude de la stabilité thermique du verre nucléaire. Modélisation de son évolution à long therme. $\mathrm{PhD}$ thesis, Université de Montpellier II, France, (1999).

[22] N. Henry, P. Deniard, S. Jobis, R. Brec, C. Fillet, F. Bart, A. Grandjean, and O. Pinet. "Heat treatment versus microstructure in molybdenum-rich borosilicates", J. Non-Cryst. Solids, 333, 199-205, (2004).

[23] E. Tomaszewicz, D. Däbrowska, S.M. Kaczmarek, and H. Fuks. "Solid-state synthesis and characterization of new cadmium and rare-earth metal molybdato-tungstates $\mathrm{Cd}_{0.25} \mathrm{RE}_{0.50}\left(\mathrm{MoO}_{4}\right)_{0.25}\left(\mathrm{WO}_{4}\right)_{0.75}(\mathrm{RE}=\mathrm{Pr}, \mathrm{Nd}, \mathrm{Sm}-\mathrm{Dy}) "$, J. Non-Cryst. Solids, 356, 2059 2065, (2010).

[24] B. Kolesov and L. Kozeeva. "Raman study of cation distribution in the scheelite-like double molybdates and tungstates”, Zhurnal Strukturnoi Khimii, 34, 52-58, (1993).

[25] S.P.S. Porto and J.F. Scott. "Raman spectra of $\mathrm{CaWO}_{4}, \mathrm{SrWO}_{4}, \mathrm{CaMoO}_{4}$ and SrMoO 4 ", Phys. Rev. B, 157, 716-719, (1967).

[26] C. Mendoza, G. Panczer, D. de Ligny, I. Bardez-Giboire, S. Schuller, and S. Peuget. "CaMOO(4) in a molybdenum-rich glass-ceramic: a spectroscopic study" Ceramic Transactions, 217, 43-55, (2010).

[27] S. Simon, I. Ardelean, S. Filip, I. Bratu, and I. Cosma. "Structure and magnetic properties of $\mathrm{Bi}_{2} \mathrm{O}_{3}-\mathrm{GeO}_{2}-\mathrm{Gd}_{2} \mathrm{O}_{3}$ glasses", Solid State Commun., 116, 83 - 86, (2000). 
[28] J. Kliava, I. Edelman, and A. Potseluyko. "EPR and magnetic properties of $\mathrm{Gd}^{3+}$ in oxide glasses”, J. Magn. Magn. Mater., 272-276, 1647-1649, (2004).

[29] R. J. Landry. "ESR and optical absorption study of $\mathrm{Mo}^{3+}$ in a phosphate glass", $J$. Chem. Phys., 48:1422-1423, (1968).

[30] O. Cozar, D. A. Magdas, and I. Ardelean. "EPR study of molybdenum-leadphosphaate glasses”, J. Non-Cryst. Solids, 354,1032-1035, (2008).

[31] D. Caurant, O. Majerus, E. Fadel, and M. Lenoir. "Effect of molybdenum on the structure and on the crystallization of $\mathrm{SiO}_{2}-\mathrm{Na}_{2} \mathrm{O}-\mathrm{CaO}-\mathrm{B}_{2} \mathrm{O}_{3}$ ", J. Am. Ceram. Soc., 90, 774783, (2007).

[32] E. Sarantopoulou, C. Raptis, S. Ves, D. Christofilos, and G. A. Kourouklis. "Temperature and pressure dependence of Raman-active phonons of $\mathrm{CaMoO}_{4}$ : an anharmonicity study", J. Phys. Condens. Matter, 14,8925, (2002).

[33] Chunhua Cui, Jian Bi, and Daojiang Gao. "Room-temperature synthesis of crystallized luminescent $\mathrm{CaMoO}_{4}$ film by a simple chemical method", Appl. Surf. Sci., 255,3463-3465, (2008).

[34] C. Luz-Lima, G. D. Saraiva, A. G. Souza Filho, W. Paraguassu, P. T. C. Freire, and J. Mendes Filho. "Raman spectroscopy study of $\mathrm{Na}_{2} \mathrm{MoO}_{4} \cdot 2 \mathrm{H}_{2} \mathrm{O}$ and $\mathrm{Na}_{2} \mathrm{MoO}_{4}$ under hydrostatic pressure", J. Raman Spectrosc., 41,576-581, (2010).

[35] V.P. Mahadevan Pillai, T. Pradeep, M.J. Bushiri, R.S. Jayasree, and V.U. Nayar. "Vibrational spectroscopic studies of $\mathrm{FeClMoO}_{4}, \mathrm{Na}_{2} \mathrm{MoO}_{4}$ and $\mathrm{Na}_{2} \mathrm{MoO}_{4} \cdot 2 \mathrm{H}_{2} \mathrm{O} / \mathrm{D}_{2} \mathrm{O}$ ", Spectrochim. Acta, Part A, 53,867-876, (1997).

[36] D. Christofilos, G.A. Kourouklis, and S. Ves. "A high-pressure Raman-study of calcium molybdates", J. Phys. Chem. Solids, 56,1125-1129, (1995). 
[37] V. Morozov, A. Arakcheeva, G. Chapuis, N. Guiblin, M. Rossell, and G. Tendeloo. "KNd($\left(\mathrm{MoO}_{4}\right)_{2}$ : A new incommensurate modulated structure in the scheelite family", Chem. Mater., 18,4075-4082, (2006). 
Figure Captions

Fig 1: EPR spectra of ceramics. Dashed line: $\mathrm{CaMoO}_{4}$ doped with 0.015 mol\% of $\mathrm{Gd}_{2} \mathrm{O}_{3}$. dotted line: $\mathrm{CaMoO}_{4}$ doped with $0.015 \mathrm{~mol} \%$ of $\mathrm{Gd}_{2} \mathrm{O}_{3}$ and charge compensated by $\mathrm{Na}_{2} \mathrm{O}$.

Fig 2: Normalized Raman spectra of ceramics. Solid line: pure $\mathrm{CaMoO}_{4}$.Dashed line:

$\mathrm{CaMoO}_{4}$ doped with $\mathrm{Gd}_{2} \mathrm{O}_{3}$. Dotted line: $\mathrm{CaMoO}_{4}$ doped with $\mathrm{Gd}_{2} \mathrm{O}_{3}$ and charge compensated by $\mathrm{Na}_{2} \mathrm{O}$. Inset: zoom on the region $860-920 \mathrm{~cm}^{-1}$.

Fig 3: EPR spectra of glass-ceramics containing $2.5 \mathrm{~mol} \%$ in $\mathrm{MoO}_{3}$ and $0.15 \mathrm{~mol} \%$ in $\mathrm{Gd}_{2} \mathrm{O}_{3}$. Solid lines correspond to as quenched samples, dashed lines correspond to $\mathrm{N}$ heat treatment and dotted lines to NG heat treatment.

Fig 4: EPR spectra of glass-ceramics containing $2.5 \mathrm{~mol} \%$ in $\mathrm{MoO}_{3}$ and $1 \mathrm{~mol} \%$ in $\mathrm{Gd}_{2} \mathrm{O}_{3}$. Solid lines correspond to as quenched samples; dashed lines correspond to $\mathrm{N}$ heat treatment and dotted lines to NG heat treatment.

Fig 5: Mean width of EPR lines attributed to $\mathrm{Gd}^{3+}$ ions incorporated into the powellite phase in samples from the series Mxg, Mxg-N and Mxg-NG. Squares: as quenched samples, circles: samples after $\mathrm{N}$ heat treatment and rhombuses: samples after NG heat treatment.

Fig 6: Raman spectra of glass-ceramics in the region $800-980 \mathrm{~cm}^{-1}$. (a) Series Mxg-N (solid lines) and Mxg1-N (dotted lines). (b) Series Mxg-NG (solid lines) and Mxg1-NG (dotted lines).

Fig 7: FWHM of the main Raman peak of powellite (peak A at $870 \mathrm{~cm}^{-1}$ ) after N and NG heat treatments.

Fig 8: Evolution of peak A FWHM with the substitution rate on the $\mathrm{Ca}$ site in $\mathrm{CaMoO}_{4}$ measured by electronic microprobe in glass-ceramics from the series Mxg-NG and Mxg1-NG. The FWHM of a non substituted powellite was measured on a pure polycrystal (square). 
Figures

Fig 1

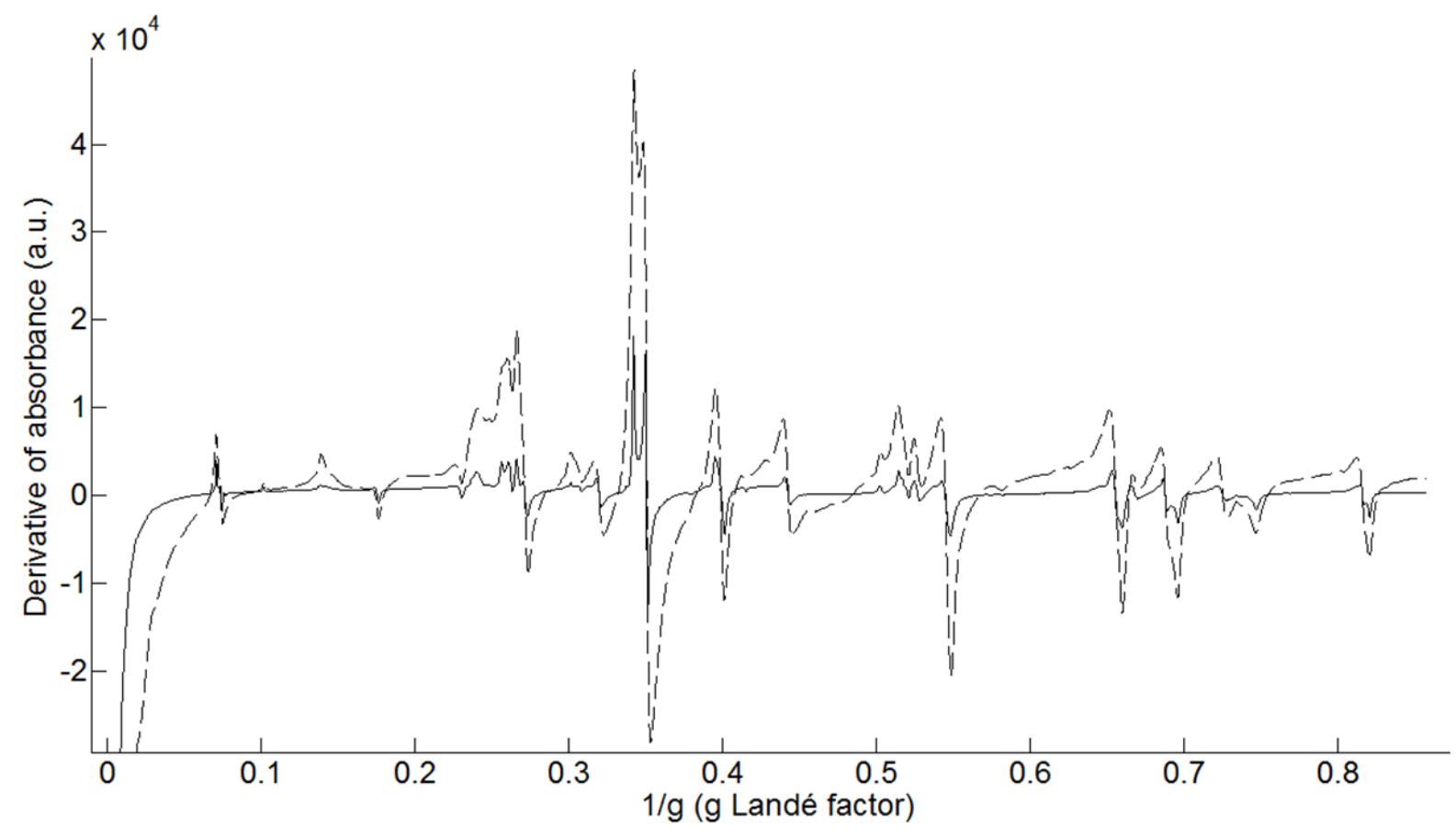


Fig 2

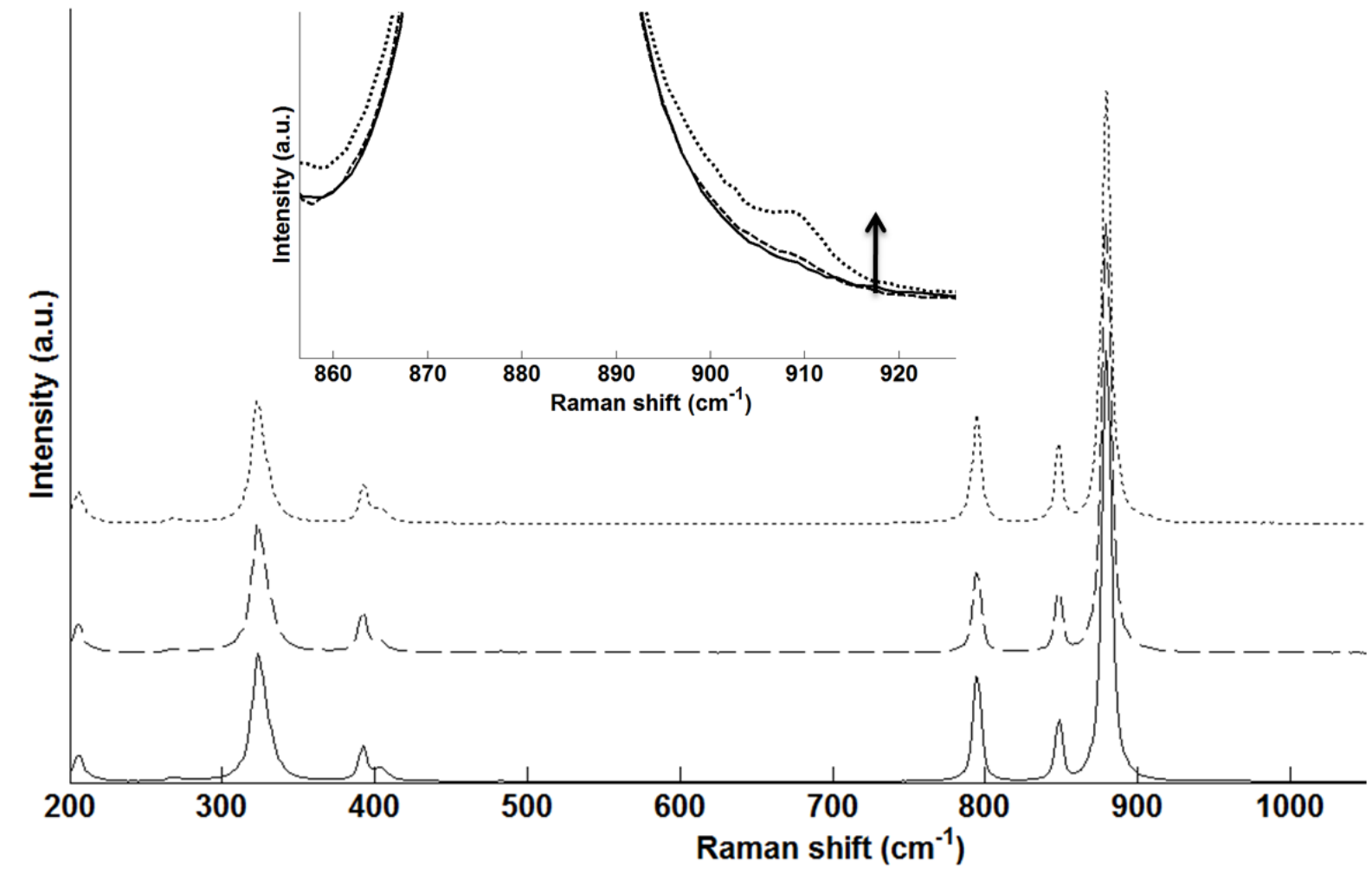


Fig 3

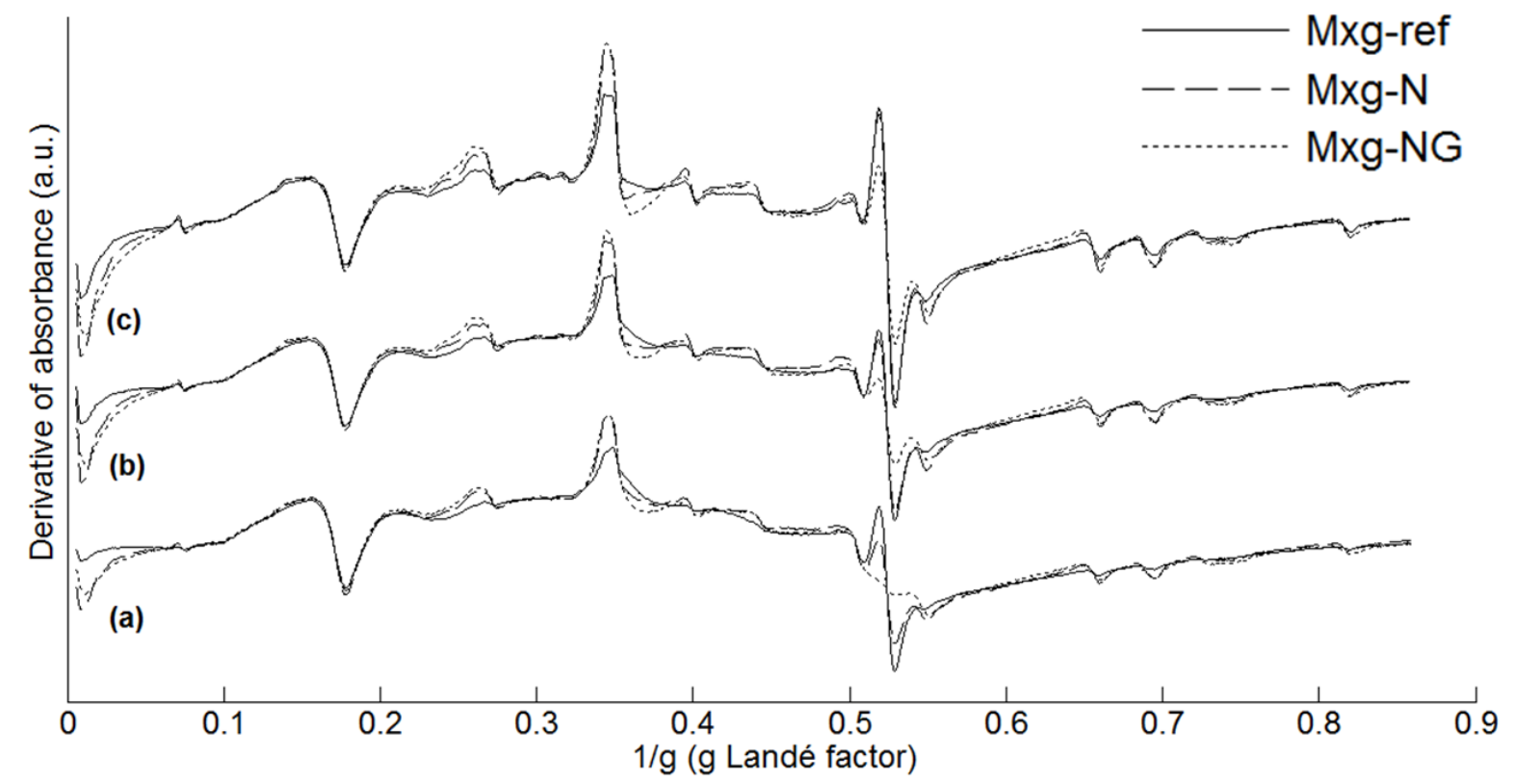


Fig 4

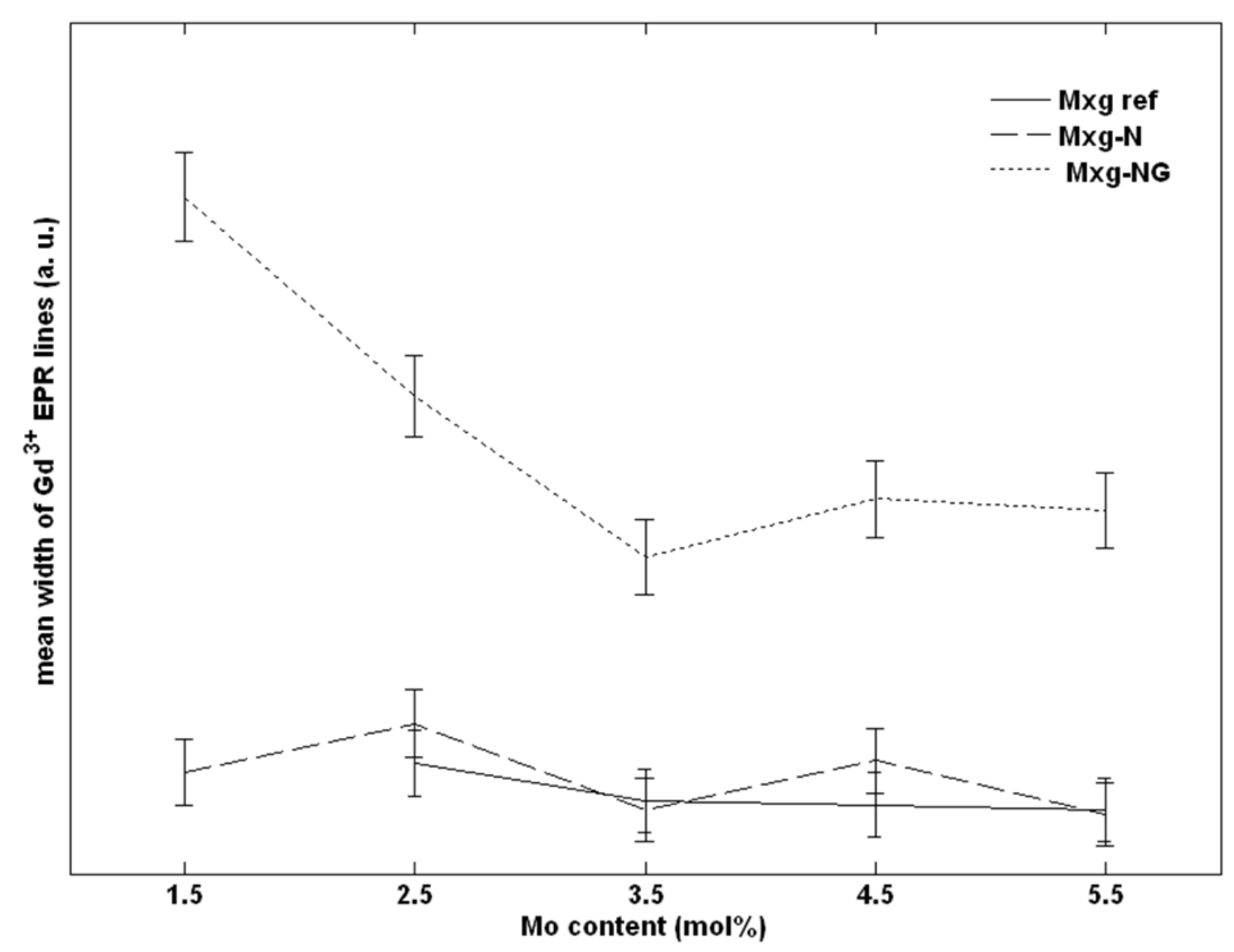


Fig 5

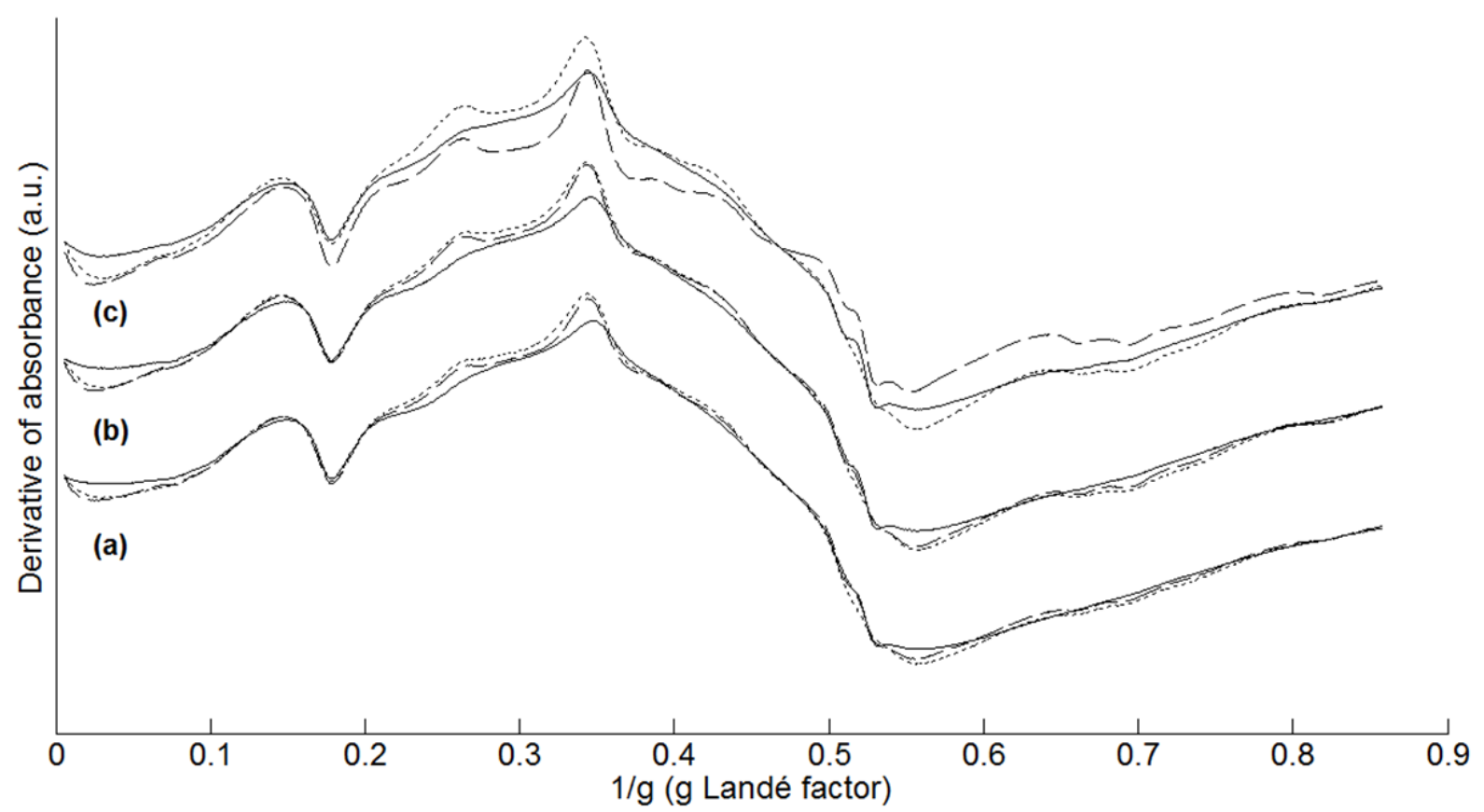


Fig 6

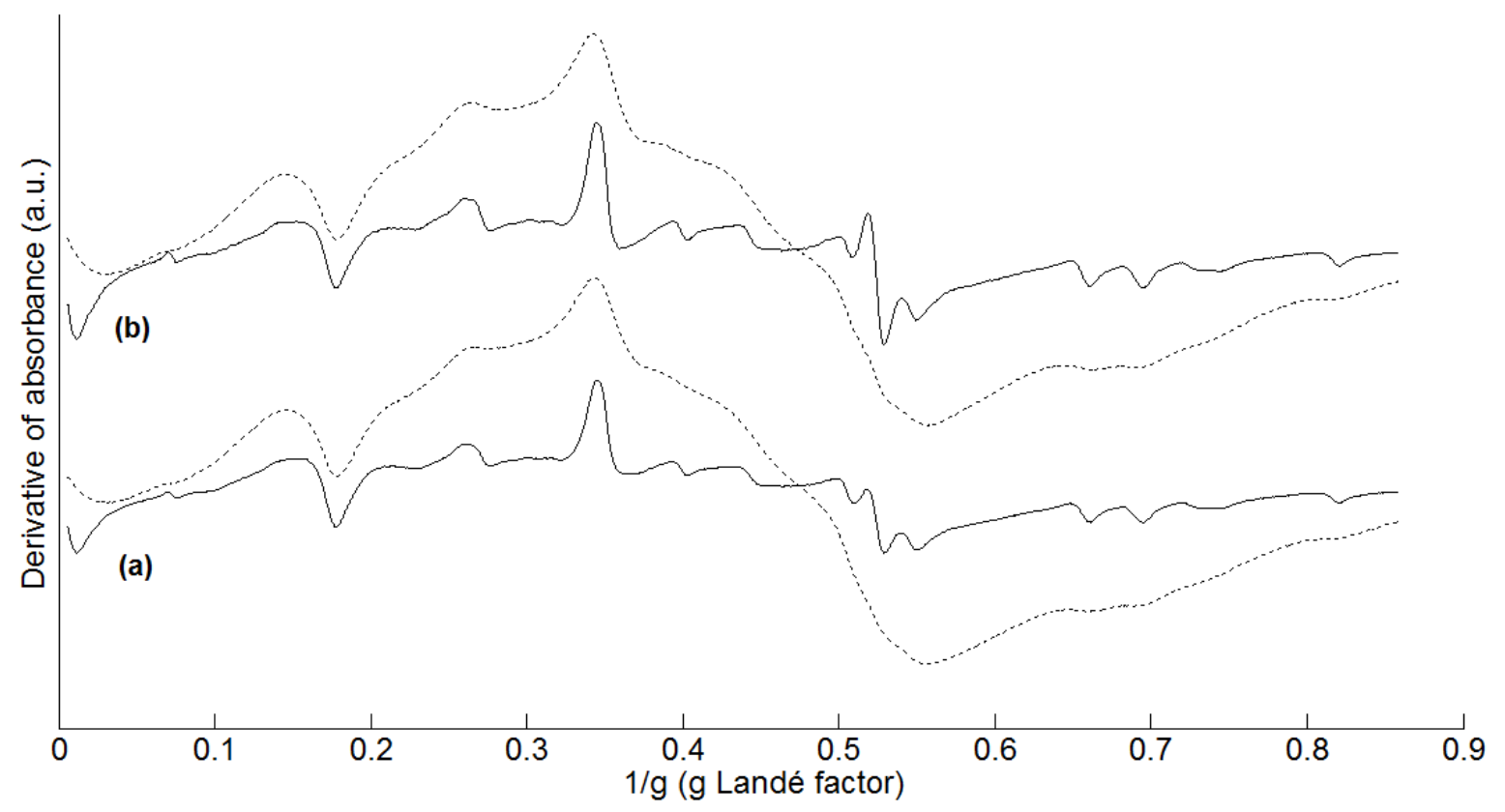


Fig 7

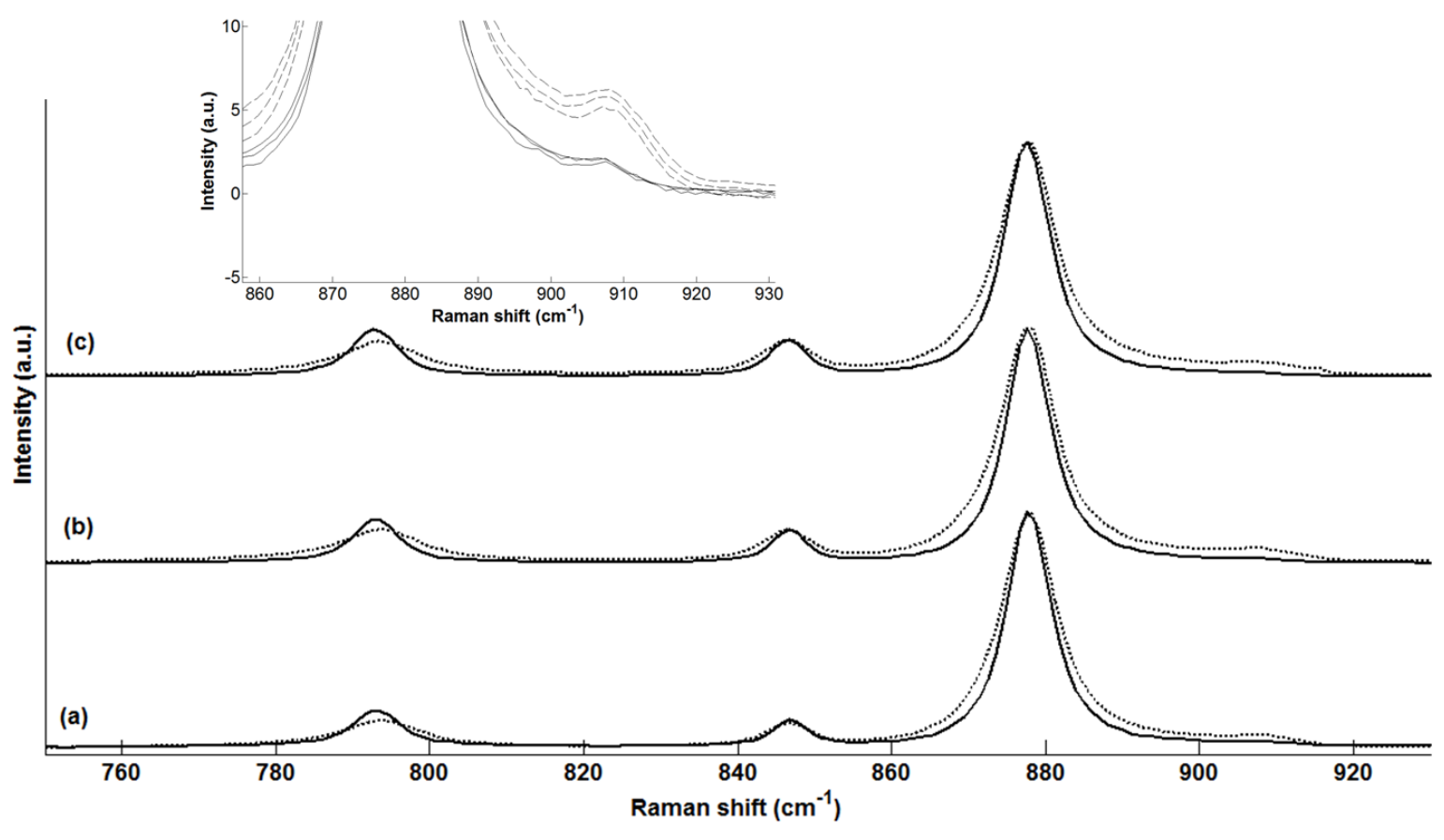


